УДК 632.4:631.51(470.45)

\title{
РАЗНООБРАЗИЕ ПОЧВЕННЫХ МИКРОМИЦЕТОВ В ПОЛЯХ ОЗИМОЙ ПШЕНИЦЫ ВОЛГОГРАДСКОЙ ОБЛАСТИ
}

\author{
Поплевина Виктория Алексеевна \\ Аспирант
}

МГУ им. М.В. Ломоносова Будынков Николай Иванович Ведущий научный сотрудник, канд. с-х. наук Михалева Светлана Николаевна Научный сотрудник ФГБНУ ВНИИФ «Всероссийский научно-исследовательский институт фитопатологии»

Аннотация: Изучали колонизацию микромицетов почвы в период весеннего кущения на полях озимой пшеницы, выращиваемой по предшественникам: «озимая пшеница», «яровая пшеница», «лён» и «нут». Образцы почвы были отобраны в хозяйствах Волгоградской области в 20172019 гг. Лабораторные исследования показали, что во всех образцах преобладали грибы рода Fusarium spp., и Mucor spp. Также практически во всех образцах почвы присутствовали бактерии родов Pseudomonas и Bacillus; во многих - грибы из родов Penicillium и Aspergillus. Значительная часть изолированных из образцов почвы микромицетов, является патогенными для культуры озимой пшеницы. Патогенные грибы рода Fusarium преобладали после колосовых предшественников и нута, токсинообразующие грибы, угнетающие и замедляющие развитие - после колосовых предшественников и льна.

Ключевые слова: озимая пшеница, почва, микромицеты, патогены, агроценоз, предшественник, токсины, грибы.

\section{VARIETY OF SOIL MICROMYCETES IN WINTER WHEAT FIELDS OF VOLGOGRAD REGION}

\section{Budynkov Nikolay Ivanovich Mikhaleva Svetlana Nikolayevna Poplevina Viktoriya Alekseyevna}

\footnotetext{
Abstract: We studied the colonization of soil micromycetes during spring tillering in the fields of winter wheat grown according to its predecessors: "winter wheat", "spring wheat", "flax"and " chickpeas". Soil samples were taken from farms 
in the Volgograd region in 2017-2019. Laboratory studies showed that all samples were dominated by fungi of the genus Fusarium spp., and Mucor spp. Also, almost all soil samples contained bacteria of the genera Pseudomonas and Bacillus; many contained fungi from the genera Penicillium and Aspergillus. A significant part of the micromycetes isolated from soil samples are pathogenic for winter wheat culture. Pathogenic fungi of the genus Fusarium predominated after ear precursors and chickpeas, toxin-forming fungi that inhibit and slow down development-after ear precursors and flax.

Key words: winter wheat, soil, micromycetes, pathogens, agrocenosis, precursor, toxins, fungi.

Пшеница, одна из важнейших зерновых и главная продовольственная культура в мире [1]. Для получения качественной зернопродукции требуется особое внимание к технике её возделывания и приемам защиты от вредных организмов. Развитие большинства вредных микроорганизмов и вредителей связано с почвой верхних слоев. Источником подобных микроорганизмов являются растительные остатки культур-предшественников, поэтому важно соблюдать севооборот и проводить регулярный мониторинг заболеваний [2].

Целью нашего исследования было изучение разнообразия микроорганизмов почвы в посевах озимой пшеницы Волгоградской области, в период весеннего возобновления кущения, по различным предшественникам.

Исследование проводили на почвенном материале производственных полей Волгоградской области, собранном с ризосферной части озимой пшеницы в лаборатории ФГБНУ ВНИИФ в 2017-2019 гг. Отбирали образцы весной, на полях с разными предшественниками: озимой и яровой пшеницы, ячменя, льна и нута. Микробиологические анализы почвы в условиях лаборатории ВНИИФ проводили по методике с использованием искусственной питательной среды Чапека. На питательную среду закладывали микрокомочки почвы с целью учета их колонизации микроорганизмами [3]. Анализ видового состава микробиоты проводили на 7-е сутки инкубации. Видовую принадлежность образующихся на питательной среде колоний микромицетов определяли по морфологии органов споруляции (конидиеносцев, конидий, асков, спор и др.) под микроскопом. При анализе образцов также оценивали встречаемость видов микромицетов. Проводили подсчет количества колоний микроорганизмов разных видов, выделенных in vitro, далее вычисляли долю (в 
\%) каждого выделенного микроорганизма относительно числа комочков почвы на питательной среде [4].

Оценили доминирующие виды выделенных микроорганизмов и их соотношение с учетом предшественника.

За весенний период 2017-2019 гг. исследований, во всех образцах и после разных предшественников, в почве преобладающими микроорганизмами являлись грибы вида Fusarium solani, уровень колонизации которых составлял от 65 до 100\%. Fusarium solani - грибной патоген, который встречается практически во всех Российских полевых агроценозах, в почве, растительных остатках и на вегетирующих растениях. Гриб в одиночку не приносит большого ущерба, но в консорциях с другими представителями рода Fusarium при благоприятных условиях окружающей среды может привести к значительным потерям урожая зерновых колосовых культур. Также во многих образцах встречались микромицеты Fusarium avenaceum с колонизацией почвенных образцов 2,5-25\% и $F$. moniliforme с колонизацией 2,5-30\%; они являются сильными патогенами, некротрофами, возбудителями гнилей и сосудистых заболеваний, поражающими озимую пшеницу. Fusarium oxysporum весной в почве встретился только в одном образце, в 2019 г. по предшественнику «яровой ячмень»с колонизацией 2,5\%. Из всех образцов почвы выделялись грибы рода Мисог - с частотой встречаемости 8,5-30\%, бактерии родов Pseudomonas - от 5 до 35\% и Bacillus - от 15 до 90\%. Грибы рода Mucor spp. являются естественными обитателями почвы и при обычных условиях не наносят никакого ущерба культурным растениям, но при появлении избыточной влажности, снижении иммунитета растений за счет других патогенов и стрессовых факторов, могут проявиться в виде активной плотной плесени в прикорневой зоне и на зерне. Pseudomonas spp. и Bacillus spp. почвообитающие бактерии. Штаммы бацилл Bacillus amyloliquefaciens, Bacillus subtilis, Bacillus thuringiensis. используются в биологической защите растений, в виде биофунгицидов и биоудобрений. Виды рода Pseudomonas могут быть относительно нейтральными обитателями почвы, патогенами культурных растений; штаммы Pseudomonas aureofaciens и Pseudomonas fluorescens антагонисты патогенной микрофлоры, являются основой многочисленных биопрепаратов для озимой пшеницы и других сельскохозяйствнных культур. В образцах 2017 и 2019гг. в полях после яровой и озимой пшеницы, выделялись бактерии Pseudomonas syringae с частотами от 2,5 до 3,3\%. При перепадах температур и возвратных заморозках их жизнедеятельность приводит к 
поражению сосудов растений. Подобными патогенными свойствами обладают и выделенные бактерии Erwinia spp. (2,5\%), которые встречались только после озимой пшеницы и нута в образцах 2018 г. и Pantea agglomerans - 2,5-3,3\% присутствовала после яровой пшеницы в 2017 и 2019 гг.

Многие виды рода Penicillium являются токсинообразующими грибами. Наиболее активные фитотоксиканты - P. Expansum и P. ciclopium [5]. Эти токсины тормозят рост и развитие культурных растений. Грибы Penicillium spp. выделялись в образцах почвы 2017 г. с уровнем встречаемости 6,7-25\% после всех предшественников и больше всего после нута. P. purpurogenum выделялся с частотами 5-22,5\% в образцах 2018 г., больше всего после зерновых предшественников. Aspergillus niger - 2,5-7,5\% был выявлен в образцах 2017 и 2018 гг. после зерновых и льна. Также в весенних образцах почвы мы в небольшом количестве, в 2017г. после зерновых предшественников и нута, наблюдали лучистые бактерии рода Actinomyces, которые являются естественными обитателями почвы, с колонизацией 2,5-5\%. Гриб-антагонист Trichoderma viride встречалась в небольшом количестве почвенных образцов (2,5-22,5\%) после зерновых колосовых предшественников, в 2017 и 2018гг., что может быть одним из показателей супрессивности почвенного биоценоза и способности почвы противостоять накоплению патогенных микроорганизмов. Неспорулирующие грибы Mycelia sterilia (2,5-15\%) выделялись после всех предшественников во все годы исследований; среди них преобладали темноокрашенные грибы, участвующие в процессах почвенной сукцессии.

\section{Список литературы}

1. Сандухадзе Б.И., Марченкова Л.А., Мамедов Р.3. Изучение адаптивности сортов озимой пшеницы на фоне искусственно создаваемых стрессов // Инновационные разработки по селекции и технологии возделывания сельскохозяйственных культур. ФИЦ «Немчиновка», 2018, с. 39-46.

2. Стойчев О.А. Защита растений в условиях специализации и концентрации сельского хозяйства. - Кишинев: Картя Молдовеняскэ, 1980. 174 c.

3. Будынков Н.И., Михалева С.Н. Болезни нута на юге Европейской территории России. Семенная инфекция // Достиж. науки и техн. АПК. 2018. Т. 32,7 , с. $31-35$. 
4. Будынков Н.И., Михалева С.Н. Растительные остатки как источник опасных микроорганизмов // Ресурсосберег. земледелие. 2015, 4(28), с. 8-12.

5. Мирчинк Т.Г., Грешных К.П. Образование токсинов в почве некоторыми видами грибов рода Penicillium. Микробиология, 1961, т.30, вып.6, c.1045-1049. 